\title{
Immunophenotypical and functional properties of equine uterine neutrophils of mares with or without degenerative endometrial changes
}

\author{
H. Zerbe', F. Engelke',3, W. Leibold'2 , H.-A. Schoon ${ }^{4}$ and E. Klug ${ }^{3}$ \\ ' Clinic for Bovine Gynaecology and Obstetrics, School of Veterinary Medicine Hanover, ${ }^{2}$ Immunology Unit, School of Veterinary Medicine Hanover \\ ${ }^{3}$ Clinic for Horses, School of Veterinary Medicine Hanover, ${ }^{4}$ Institute for Veterinary Pathology, University Leipzig
}

\begin{abstract}
Summary
A model system for equine endometritis was developed. The system is based on the controlled, stimulated immigration of polymorphonuclear neutrophil granulocytes (PMN) from peripheral blood into the uterine lumen. After intrauterine application of recombinant human interleukin8 (rhlL-8) (0.5-1.25 ng in $50 \mathrm{ml}$ phosphate buffered saline solution; PBS), the uteri were flushed with PBS and immigrated PMN were checked for absolute numbers, viability, morphology, phenotype, generation of reactive oxygen species (ROS) and phagocytic activity by means of quantitative and qualitative flow cytometric assays. Recombinant hIL-8 reliably attracted high numbers of viable PMN into the uterus of mares with or without degenerative endometrial changes. Compared with blood PMN, immigrated uterine neutrophils displayed significant phenotypical and functional differences: The expression of CD1 1a/CD18 (LFA-1) was upregulated on uterine PMN whereas MHC class I and CD44 molecules were expressed at lower densities. The ability to phagocytose opsonised streptococci did not differ between uterine and blood PMN. However, uterine PMN displayed a higher capacity to generate ROS.

Recombinant hIL-8 was also able to attract PMN (in comparable numbers and viability) into the uteri of mares with histologically proven degenerative endometrial changes. Compared to autologous blood PMN, the uterine PMN showed on average similar phenotypical and functional characteristics as in mares with histologically healthy endometrium. However, immigrated PMN of the mares with degenerative endometrial changes displayed relatively high or exceptionally low activities to generate ROS.

Taken together, the described model system offers the possibility to characterize a multitude of functional and phenotypical characteristics of cells attracted into the uterus and, also, the action of modulating therapeutic agents. The system may be an useful instrument to answer specific questions regarding the pathogenesis of persisting endometritis in horses.
\end{abstract}

Keywords: $\quad$ mare, endometritis model, PMN, endometrial degeneration

\begin{abstract}
Immunphänotypische und funktionelle Eigenschaften uteriner neutrophiler Granulozyten mit und ohne degenerativen Veränderungen des Endometriums

In der Arbeit wird ein neues Endometritismodell für die Stute vorgestellt. Das Modellsystem basiert auf der kontrollierten, stimulierten Immigration von polymorphkernigen neutrophilen Granulozyten (PMN) vom Blut in den Uterus. Nach intrauteriner Applikation von rekombinantem humanem Interleukin-8 (rhlL-8) (0.5-1.25 ng in 50 ml PBS) wurde der Uterus mit PBS gespült. Die immigrierten PMN wurden dann quantifiziert und anhand ihrer Vitalität, Morphologie, Immunphänotyp, Bildung reaktiver Saverstoffspezies (ROS) und ihrer Kapazität zur Phagozyłose durchflusszytometrisch charakterisiert. Rekombinantes hIL-8 lockte zuverlässig große Mengen vitaler PMN in den Uterus von Stuten mit oder ohne degenerativen Veränderungen des Endometriums. Verglichen mit Blut-PMN wiesen Uterus-PMN signifikante immunphänotypische und funktionelle Veränderungen auf. Die Expression von CD 11 a/CD1 8 (LFA-1) war auf uterinen PMN erhöht, während MHC-Klasse I und CD44 mit geringerer Dichte exprimiert waren. Die Kapazität zur Phagozytose opsonisierter Streptokokken unterschied sich bei PMN aus Blut und Uterus kaum. Dagegen zeigten uterine PMN eine erhöhte ROS-Bildung.

Rekombinantes hlL-8 induzierte auch bei Stuten mit histologisch nachgewiesenen degenerativen Veränderungen des Endometriums einen zahlenmäßig starken Influx neutrophiler Granulozyten mit hoher Vitalität. Gemessen an autologen Blut-PMN wiesen uterine PMN durchschnittlich ähnliche immunphänotypische und funktionelle Eigenschaften wie Stuten mit histologisch gesundem Endometrium auf. Die PMN der Stuten mit degenerativen Endometriumveränderungen zeigten jedoch teilweise relativ hohe oder aber außergewöhnlich niedrige Aktivitäten bei der ROS-Bildung.

Das Endometritismodellsystem bietet die Möglichkeit, eine Vielzahl immunphänotypischer und funktioneller Parameter in den Uterus gelockter Zellen sowie deren Modulation durch Medikamente zu charakterisieren. Es könnte ein nützliches Instrument bei der Beantwortung von Fragen zur Pathogenese der persistierenden Endometritis der Stute sein.
\end{abstract}

Schlüsselwörter: Stute, Endometritismodell, PMN, Endometriumsdegeneration

\section{Introduction}

Endometritis in mares results from complex interactions between opportunistic uterine bacterial pathogens and host factors. Bacterial infection during mating usually resolves within few hours or days (Evans et al., 1986; Watson, 1988), and the uterus remains free of infection before the embryo enters the uterine cavity. Some mares are susceptible to persistent endometritis with chronic inflammation, which can result in degenerative changes and reduced fertility (Hughes and Loy, 1969; Kenney, 1978). It has been suggested that inability to spontaneously eliminate bacterial infection from the uterus is associated with 
an impaired local uterine immune response. The local uterine defence mechanisms that are responsible for the resolution of bacterial contamination include neutrophilic phagocytosis and antibody-mediated mechanisms (Watson, 1988). Neutrophilic phagocytic activity seems to be an important factor of uterine defence in the mare (Liv et al., 1986; Troedsson, 1999).

Several studies revealed that neutrophils obtained from the uterine lumen of mares susceptible to endometritis have an impaired functional capacity (especially phagocytic activity) compared to those obtained from blood (Cheung et al., 1985; Watson et al., 1987). In contrast, Asbury and Hansen (1987) found that the phagocytic capacity of uterine PMN collected 4 hours after infection was greater for susceptible than for resistant mares if given the right environment. In conclusion, insufficient complement in uterine secretions and impaired opsonisation were suggested to be responsible for a lower phagocytic activity of uterine PMN (Troedsson et al., 1993). However, the effect of neutrophil functional abilities on susceptibility to endometritis remains unclear.

In order to develop effective therapeutic approaches, it is necessary to understand more about the regulation of PMN migration and the modulation of their functional and phenotypic qualities during migration to the extravascular tissue. In the framework of investigations to pathogenic mechanisms of endometritis in mares, we were studying the immigration of polymorphonuclear neutrophil granulocytes (PMN) into the uterus. Using a new developed endometritis model we compared their properties with those of contemporarily harvested PMN from peripheral blood in mares with histologically proven normal endometrium or with degenerative endometrial changes.

\section{Material and methods}

Animals

Total of 15 clinically healthy mares were included into the investigations. No bacterial growth was obtained by examination of the uterine flushings before starting the experiments. Seven mares aged 3-12 years with grade I or lla categorised endometrial biopsies represent group A. Eight mares aged 620 years with grade IIb or III categorised endometrial biopsies represent group B. Group B mares were barren between 1 and 3 years.

\section{Collection and isolation of PMN}

After a zero flush with $50 \mathrm{ml}$ of sterile PBS, $50 \mathrm{ml}$ of a solution of the chemokine recombinant human interleukin 8 (rhIL-8; 10 or $25 \mathrm{ng} / \mathrm{ml}$ PBS; Cellconcept) were introduced into the uterus using a Foley catheter. Migrated leukocytes were harvested 3, 6 and 24 h after rhlL- 8 infusion by flushing the uterus with $5 \times 50$ $\mathrm{ml}$ PBS. Immediately after uterus flushing venous blood was taken and PMN were isolated by blood sedimentation and Percoll density gradient centrifugation. Blood and uterus cells were washed with PBS and resuspended in medium to a final concentration of $2 \times 10^{6} / \mathrm{ml}$.
Cell counts, differentiation, determination of cellular viability

Total blood and uterus leukocyte concentrations were determined in a cell counting chamber after staining with Turk's solution (Merck). Differential counts (granulocytes, lymphocytes and monocytes) were determined by flow cytometry (FACScan ${ }^{\circledR}$, Becton Dickinson) after acquisition of at least 5,000 leukocytes. Cellular suspensions contained propidium iodide $(2 \mu \mathrm{g} / \mathrm{ml}$, Calbiochem) for the assessment of cellular viability.

Immunophenotypical and functional characterisation of PMN

Immunophenotypical and functional characterisation of PMN were evaluated according to methods previously described for bovine PMN (Zerbe et al., 2000). The assessment of phenotypic analysis of PMN was done by flow cytometry upon indirect immunofluorescence using monoclonal antibodies: mAb CZ4 (anti MHC class I); mAb CZ1 1 (anti MHC class II); mAb CZ3. 1 (EqCD1 1a/18; LFA1); mAb CZ5.15 (EqCD44); mAb 72.87 (BoCD1 1a; a-chain of LFA-1); mAb 25.32 (BoCD44). For the evaluation of the phagocytic capacity of PMN a nonviable streptococcus suspension (Omnisorbin ${ }^{\circledR}$, Calbiochem) was labelled by FITC (Sigma). After opsonisation with equine serum, the bacteria were mixed with PMN suspension followed by incubation. PMN which ingested labelled bacteria displayed increased green fluorescence after flow cytometric analysis. Generation of reactive oxygen species (ROS) in Dihydrorhodamin 123-labelled PMN (Molecular probes) was evaluated flow cytometrically after stimulation with phorbol myristate acetate (PMA; Sigma).

\section{Results and discussion}

Due to the suggestion that dysfunctional uterine PMN could be responsible for the inability to spontaneously eliminate of bacterial infections from the uterus, a new model system for the endometritis in mares was developed. In several studies, suspensions of Streptococcus zooepidemicus or oysterglycogen served as inducer of experimental inflammation (Liv et al., 1986; Troedsson et al., 1990). High amounts of uterine PMN could be isolated, but the effect of these substances on subsequent functional assays with uterine neutrophils remains unclear. In this work, the controlled selective immigration of PMN into the uterus was induced by the well defined chemokine rhIL-8 (10$25 \mathrm{ng} / \mathrm{ml}$ ). Because of its chemoattractant properties, this physiological mediator plays an important role in neutrophil accumulation during inflammation. The amount of harvested uterine PMN (on average 6x107 PMN per flush in group A; PMN-purity $>98 \%$; viability $>95 \%$ ) and the kinetic of the neutrophilic influx with a peak at 6 hours after infusion of rhlL- 8 are comparable with the results of other endometritis models in the mare (Liv et al., 1986; Williamson et al., 1987; Troedsson et al., 1990). Degenerative endometrial changes do not result in a decreased influx of neutrophils into the mares uterus. Recombinant hIL-8 was also able to attract PMN (in comparable numbers and viability) into the uteri of group $B$ mares. 
The described model system offers the possibility to characterize a multitude of functional and phenotypical characteristics of attracted cells into the uterus. When compared to autologous blood PMN, the uterine PMN showed on average comparable phenotypical and functional characteristics as in mares with or without degenerative endometrial changes. The expression of CD1 1 a/CD18 (LFA-1) was upregulated on uterine PMN whereas MHC class I and CD44 molecules were expressed at lower densities (Tab. 1). These results conflict in part with our observations in a similar rhlL-8 using endometritis model in the cow (unpublished). In fact bovine uterine PMN showed a reduced $\mathrm{MHC}$ class I expression also. On the other hand the neutrophilic expression of CD11a/CD18 was significantly downregulated in the cows uterus.

The ability to phagocytose opsonised streptococci did not differ between uterine and blood PMN (Tab. 1). This is according to previous reports, where an undisturbed phagocytosis in susceptible mares was found (Troedsson et al., 1990). Uterine PMN displayed a higher capacity to generate ROS. These results agree with those obtained with our own endometritis model in the cow (unpublished).

Tab. 1: Immunophenotypical and functional characteristics of equine uterine PMN in comparison to PMN from blood

Immunphänotypische und funktionelle Eigenschaften equiner uteriner PMN im Vergleich zu Blut-PMN

\begin{tabular}{|l|c|}
\hline PMN parameter & $\begin{array}{r}\text { uterine PMN in comparison } \\
\text { to blood PMN }\end{array}$ \\
\hline CD1 1a/CD18 expression & $\uparrow$ \\
\hline MHC class I expression & $\downarrow$ \\
\hline CD44 expression & $\downarrow$ \\
\hline phagocytic capacity & $=$ \\
\hline Killing capacity (ROS generation) & $\uparrow$ \\
\hline
\end{tabular}

However, in some mares with degenerative endometrial changes, immigrated PMN displayed an exceptionally low activity to generate ROS, whereas in other cases the ROS generation was relatively high. For further investigations it would be useful to compare the control animals (group A) with mares susceptible to persistent endometritis. This could show, whether these mares show an impaired killing of ingested material compared to resistant mares.

Taken together, the described model system offers the opportunity to investigate a number of functional and phenotypical characteristics of cells attracted into the uterine lumen and, also, the action of modulating therapeutic agents. The system may be an useful instrument to answer specific questions regarding the pathogenesis of persisting endometritis in horses.

\section{Literature}

Asbury, A. C. and Hansen, P. J. (1987): Effects of susceptibility to endometritis and stage of cycle on phagocytic activity of uterine derived neutrophils. J. Reprod. Fertil. Suppl. 35, 311-316.

Cheung, A. T., Liu, I. K. M., Walsh, E. M. and Miller, M. E. (1985): Phagocytic and killing capacities of uterine-derived polymorphonuclear leukocytes from mares resistant and susceptible to chronic endometritis. Am. J. Vet. Res. 46, 1938-1940.

Evans, M. J., Hamer, J. M., Ganson, L. M., Graham, C. S., Asbury, A. C. and Irvine, C. G. H. (1986): Clearance of bacteria and nonantigenic markers following intra-uterine inoculation into maiden mares: effect of steroid hormone environment. Theriogenology 26, 37-50.

Hughes, J. P. and Loy, R. G. (1969): Investigations on the effect of intrauterine inoculation of Streptococcus zooepidemicus in the mare. Proc. Am. Assoc. Equine Pract. 15, 289-292.

Kenney, R. M. (1978): Cyclic and pathological changes of the mare endometrium as detected by biopsy, with a note on early embryonic death. J. Am. Vet. Med. Ass. 172, 241-262.

Liu, I. K., Cheung, A. T. W., Walsh, E. M., Ayin, S. (1986): The functional competence of uterine-derived polymorphonuclear neutrophils (PMN) from mares resistant and susceptible to chronic uterine infection: A sequential migration analysis. Biol. Reprod. 35, 1168-1174.

Troedsson, M. H. T. (1999): Uterine clearance and resistance to persistent endometritis in the mare. Theriogenology 52, 461-471.

Troedsson, M. H. T., Concha, C., Einarsson, S. and Holmberg, O. (1990): A preliminary study of uterine derived polymorphonuclear cell function in mares with chronic uterine infection. Acta Vet. Scand. 31, 187-192.

Troedsson, M. H. T., Liu, I. K. M. and Thurmond, M. (1993): Immunoglobulins ( $\lg G$ and $\lg A$ ) and complement (C3) concentrations in uterine secretion following an intrauterine challenge of Streptococcus zooepidemicus in mares susceptible versus resistant to chronic uterine infection. Biol. Reprod. 49, 502-506.

Watson, E. D. (1988): Uterine defense mechanisms in mares resistant and susceptible to persistent endometritis: a review. Equine Vet. J. 20, 397-400.

Watson, E. D., Stokes, C. R. and Bourne, F. J. (1987): Cellular and humoral defense mechanisms in mares susceptible and resistant to persistent endometritis. Vet. Immunol. Immunopathol. 16, 107-121.

Williamson, P., Munya, S., Martin, R. and Penhale, J. (1987): Dynamics of the acute uterine response to infection, endotoxin infusion and physical manipulation of the reproductive tract of the mare. J. Reprod. Fert. Suppl. 35, 317-325.

Zerbe, H., Schneider N., Leibold, W., Wensing, T., Kruip, T. A. M., Schuberth, H. J. (2000): Altered functional and immunophenotypical properties of neutrophilic granulocytes in post partum cows associated with fatty liver. Theriogenology 54, 771-786.

\section{Dr. H. Zerbe}

Klinik für Geburtshilfe und Gynäkologie des Rindes

Tierärztliche Hochschule Hannover

Bischofsholer Damm 15

30173 Hannover

Tel.: 0049-51 1-8567611/7222

Fax.: 0049-51 1-856 7691

Holm.Zerbe@tiho-hannover.de 